\title{
PENINGKATAN PEMAHAMAN AKUNTANSI MELALUI WORKSHOP BINA PRESTASI
}

\author{
Juli Murwani $^{1^{*}}$, Titin Ervita Munawaroh ${ }^{2}$ \\ ${ }^{1 *}$ Universitas PGRI Madiun \\ jmurwani@unipma.ac.id \\ ${ }^{2}$ Universitas PGRI Madiun \\ titinyoung02@gmail.com
}

\begin{abstract}
ABSTRAK
Kegiatan pelaksanaan program workshop bina prestasi dilaksanakan untuk meningkatkan pendalaman materi akuntansi di SMKN 1 Geger. Pendalaman materi ini digunakan untuk persiapan siswa mengikuti ajang olimpiade yang akan dilaksanakan oleh siswa SMKN 1 Geger. Adanya kegiatan pengabdian workshop bina prestasi bertujuan untuk memberikan strategi yang lebih mudah dan menyenangkan untuk belajar akuntansi sehingga siswa lebih efektif memahami cara pengerjaan soal dengan mudah sesuai dengan pengalaman belajar dengan menggunakan strategi belajar yang cukup praktis dan menyenangkan. Hasil setelah adanya kegiatan workshop bina prestasi adalah dapat meningkatkan soft skill siswa dalam mengerjakan soal-soal akuntansi dengan baik terlihat dari siswa dapat menjawab dengan tepat, siswa terlihat bekerja sama dengan tim dan mulai terlihat kemandirian siswa dalam menjawab pertanyaan pada waktu di tanya oleh tim pengabdian masyarakat.
\end{abstract}

Kata Kunci: Akuntansi; bina prestasi; workshop

\begin{abstract}
Activities the implementation of the achievement building workshop program was carried out to improve the depth of accounting material at SMKN 1 Geger. The deepening of this material is used to prepare students to take part in the Olympics which will be carried out by students of SMKN 1 Geger. The existence of achievement building workshop service activities aims to provide an easier and more enjoyable strategy for learning accounting so that students can more effectively understand how to work on questions easily in accordance with the learning experience using learning strategies that are quite practical and fun. The result after the achievement building workshop activity is that it can improve students' soft skills in working on accounting questions properly. It can be seen from the students being able to answer correctly, students are seen working with the team and students are starting to see independence in answering questions when asked by the research team.
\end{abstract}

Keywords: Accounting; performance building; workshop 


\section{PENDAHULUAN}

Terdapat beberapa karakteristik siswa dalam menyelesaikan persoalan terkait pembelajaran akuntansi. Karakteristik itulah yang menjadikan siswa memiliki pengalaman belajar dalam menyelesaikan materi pembelajaran akuntansi. Dari cara pikir dan penyelesaian masalah yang berbeda-beda itulah yang perlu adanya pendampingan untuk dapat memfasilitasi pola pikir siswa. Pengetahuan Akuntansi prosesnya bersifat kompleks dan prosedural serta memadukan aktivitas intelektual, sosial dan emosi secara dinamis. Syaodih dan Lisnawati (2018) adanya pendampingan siswa dapat menemukan dan menjadi solusi yang tepat dalam mengatasi kesulitan belajar siswa.

SMKN 1 Geger merupakan sekolah yang telah melaksanakan bimbingan secara intens kepada siswa berbakat dan minat dalam mengikuti perlombaan serta olimpiade di tingkat SMK sederajat. Kegiatan Bina Presitasi merupakan langkah yang dilaksanakan SMK N 1 Geger mempersiapkan siswa dalam berkompetisi diajang olimpiade baik itu tingkat lokal maupun tingkat nasional. Persiapan ini dilaksanakan untuk memudahkan siswa untuk dapat belajar lebih intensif dan juga membekali siswa dalam menyelesaikan studi kasus dan juga materi tekait dengan bidang akuntansi dan keuangan. Adanya program bina prestasi dimungkinkan dapat meningkatkan soft skill siswa (Khoirul, 2019). Dengan adanya aktivitas yang di lakukan siswa dalam pembelajaran dapat menjadi kelas lebih hidup sebagaimana aktivitas dalam kehidupan di masyarakat karena siswa aktif dalam belajar (mencari pengalaman) dan langsung mengalami sendiri kegiatan pembelajaran (Nurmala et al., 2014).

Workshop Bina Prestasi ini merupakan kerja sama tim pengabdian masyarakat dengan pihak sekolah. Dimana dalam pelaksanaannya membantu pihak sekolah dalam mengarahkan, membimbing serta memberikan strategi pemecahan masalah terkait dengan bidang akuntansi dan keuangan. Demikian pemilihan metode mengajar yang tepat dapat memberikan andil besar dalam meningkatkan prestasi belajar akuntansi (Susilowati et al., 2013).

Adanya pelaksanaan pengabdian ini diharapkan memberikan pendampingan dalam mempersiapkan siswa dalam mengikuti berbagai perlombaan dan olimpiade tingkat lokal maupun nasional. Memberikan pengetahuan siswa dalam menghadapi permasalahan dan 
solusi pemecahan masalah terkait dengan materi akuntansi, sehingga diharapkan siswa lebih siap dan dapat lebih bertanggung jawab serta dapat mandiri dalam berkompetisi.

\section{METODE}

Metode pelaksanaan kegiatan pengabdian masyarakat ini berlangsung selama 3 hari yaitu mulai tanggal 28 Oktober 2019 sampai dengan 30 Oktober 2019. Kegiatan ini terdiri dari beberapa tahapan diantaranya adalah tahap persiapan, sosialisasi, pendampingan siswa dan evaluasi. Adapun uraian dari masing-masing sebagai berikut:

1. Persiapan

Pada tahap persiapan tentunya tim pengabdian masyarakat terlebih dahulu melakukan koordinasi dengan pihak sekolah. Koordinasi ini digunakan utuk mengetahui permasalahan terkait siswa dalam memahami materi akuntansi dan juga kesulitan guru dalam mendampingi siswa dalam persiapan lomba dan juga olimpiade.

2. Sosialisasi

Kegiatan sosialisasi bertujuan menjajaki antusias dan minat siswa dalam mengikuti lomba dan olimpiade, serta menanyakan lebih lanjut permasalahan terkait dengan penyelesaian dan studi kasus yang ada dalam materi akuntansi.

3. Pendampingan

Pelaksanaan pendampingan dilakukan sesuai dengan kondisi dan juga karakteristik dari siswa setelah melaksanakan sosialisasi. Pendampingan ini digunakan untuk memberikan metode belajar yang tepat, menyenangkan dan efektif dalam proses belajar.

4. Evaluasi

Kegiatan yang terakhir adalah evaluasi dalam kegiatan evaluasi ini digunakan untuk mengetahui pemahaman siswa sebelum dan sesudah diadakannya program pengabdian masyarakat ini.

\section{HASIL DAN PEMBAHASAN}

Kegiatan Pengabdian masyarakat ini terlaksana hasil kerja sama tim pengabdian masyarakat dengan pihak sekolah yaitu SMKN 1 Geger. Sebelum pelaksanaan kegiatan terlaksana, pada tanggal 21 Oktober 2019 tim pengabdian masyarakat menemui kepala 
sekolah untuk berkoordinasi terkait dengan kendala dan permasalahan yang dihadapi guru dalam mempersiapkan siswa untuk kegiatan lomba dan olimpiade. Kepala sekolah pun menjelaskan ada beberapa faktor salah satunya adalah siswa masih kurang bisa mengatur jam belajar sehingga diperlukan pendampingan yang ekstra dalam mempersiapakan siswa dalam mengikuti kompetisi lomba dan juga olimpiade. Setelah adanya koordinasi dengan kepala sekolah, akhirnya koordinasi terkait jadwal dan juga observasipun dilakukan dengan guru pengampu mata pelajaran akuntansi. Dari hasil diskusi inilah diteruskan dengan pelaksanaan kegiatan pengabdian masyarakat.

Pelaksanaan hari pertama dimulai pada tanggal 28 Oktober 2019, kegiatan yang dilakasanakan berupa pre-test dan juga sosisalisasi terkait dengan pemahaman dan strategi yang tepat dalam menyelesaikan soal akuntansi. Pada kegiatan sosialisasi ini selain memberikan pengarahan dan juga motivasi kepada siswa, tim pengabdian masyarakat mencoba untuk berinteraksi lebih mendalam kepada siswa terkait permasalahan yang dialami dalam menyelasikan materi akuntansi. Siswa pun mengungkapkan permasalahan dan juga kendala yang mereka alami saat belajar akuntansi terutama menjelang lomba dan olompiade.

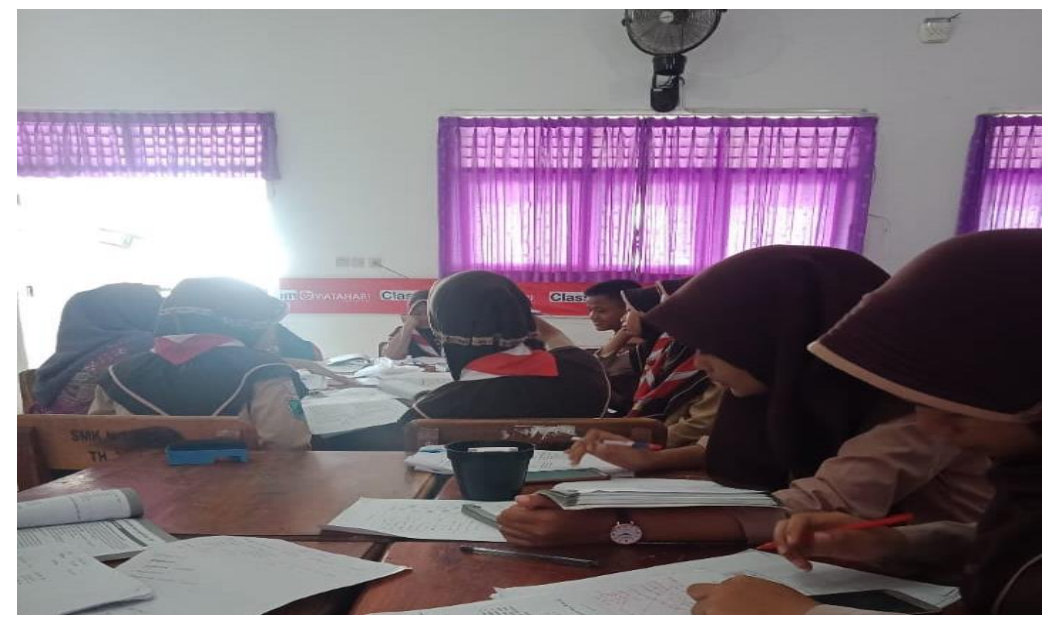

Gambar 1. Siswa Mengerjakan Soal Pre-Test

Pelaksanaan pre-test berlangsung dengan lancar, semua siswa mencoba menjawab pertanyaan dengan konsep yang dimiliki masing-masing. Siswa mengerjakan dengan tenang dan tertib sesuai dengan waktu yang ditentukan meskipun diakhir-akhir waktu akan habis, siswa terlihat panik dan terlihat tergesa-gesa tapi mereka berusaha menyelesaikan soal dengan tepat waktu. 
Pelaksnaan hari kedua yaitu tanggal 29 Oktober 2019. setelah adanya sosialisasi dihari pertama maka kegiatan hari kedua diisi dengan pendampingan. pendampingan ini dilaksanakan sesuai dengan kondisi siswa dan metode yang digunakan untuk pendampingan ini menyesuaikan dari pada hasil jawaban dari sosialisasi dan hasil pengerjaan soal pre-tes yang dilaksanakan pada hari pertama. Metode yang diberikan meliputi memberikan trik dan tips dengan cara yang sederhana dan mudah dalam mengerjakan soal. Pendampingan pemberian materi ini diharapkan dapat memberikan kemudahan siswa untuk lebih efektif dan efisien dalam mengerjakan soal. Konsep dalam pendampingan ini terdiri dari pemberian soal-soal yang sudah dipersiapkan oleh tim pengabdian masyarakat. Pemilihan soal ini berdasarkan bank soal perlombaan dan juga olompiade, dengan demikian diharapkan siswa akan terlatih dan lebih paham menjawab pertanyaan dan permasalahan terkait dengan materi akuntansi.

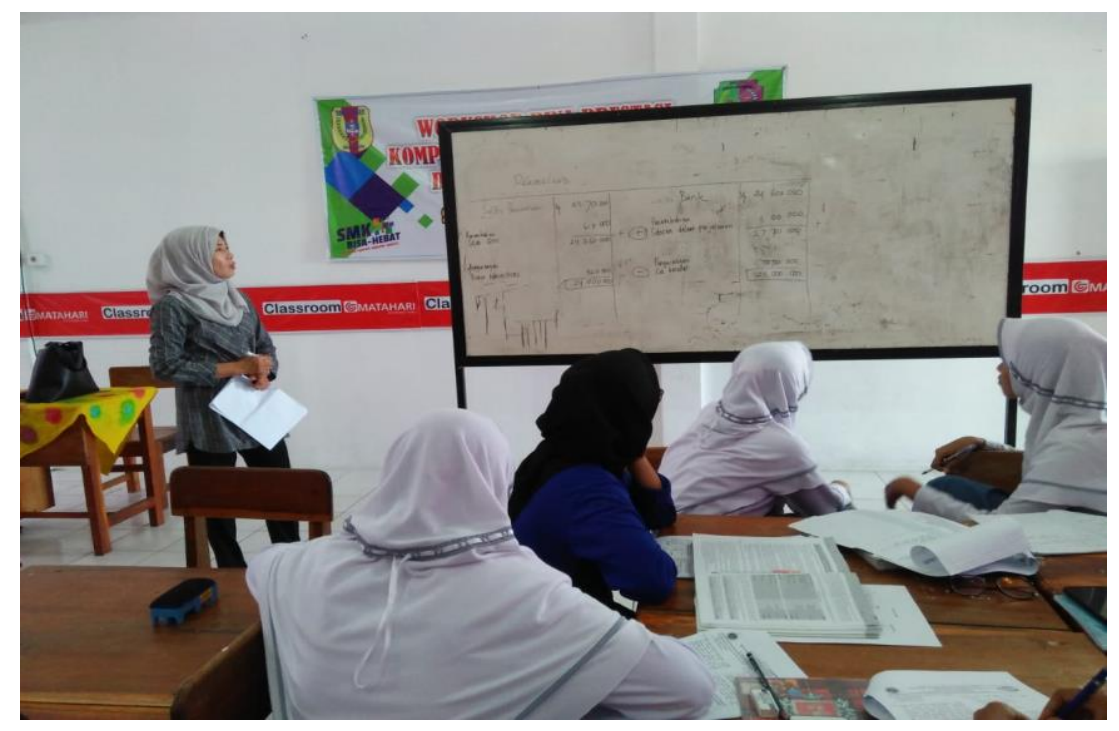

Gambar 2. Kegiatan Pendampingan Siswa

Pada tahap pendampingan ini siswa terlihat aktif bertanya dan juga menjawab pertanyaan. Siswa berusaha memberikan jawaban sesuai dengan pengalaman belajar siswa tersebut dan kemuadian pendamping memberikan masukan dan solusi pengembangan dari jawaban yang sudah diberikan kepada siswa. Suasana kelas terlihat menyenangkan dan kondusif. 
Hari ketiga dilaksankan pada tanggal 30 Oktober 2019. Kegiatan ini diawali dengan pembahasan soal-soal dan juga simulasi dalam debat dan menjawab pertanyaan. Pada pertemuan ketiga ini siswa terlihat mengikuti kegiatan dengan baik, hal ini terlihat adanya umpan balik siswa dan juga siswa terlihat dapat bekerja sama dengan tim dan berusaha untuk kompak. Setelah kegiatan simulasi ini belangsung maka diakhiri dengan evaluasi yaitu memberikan soal dan juga pembahasan serta movitasi kepada siswa. Motivasi ini diberikan untuk mempersiapkan siswa dalam menghadapi perlombaan dan juga olimpiade yang akan datang.

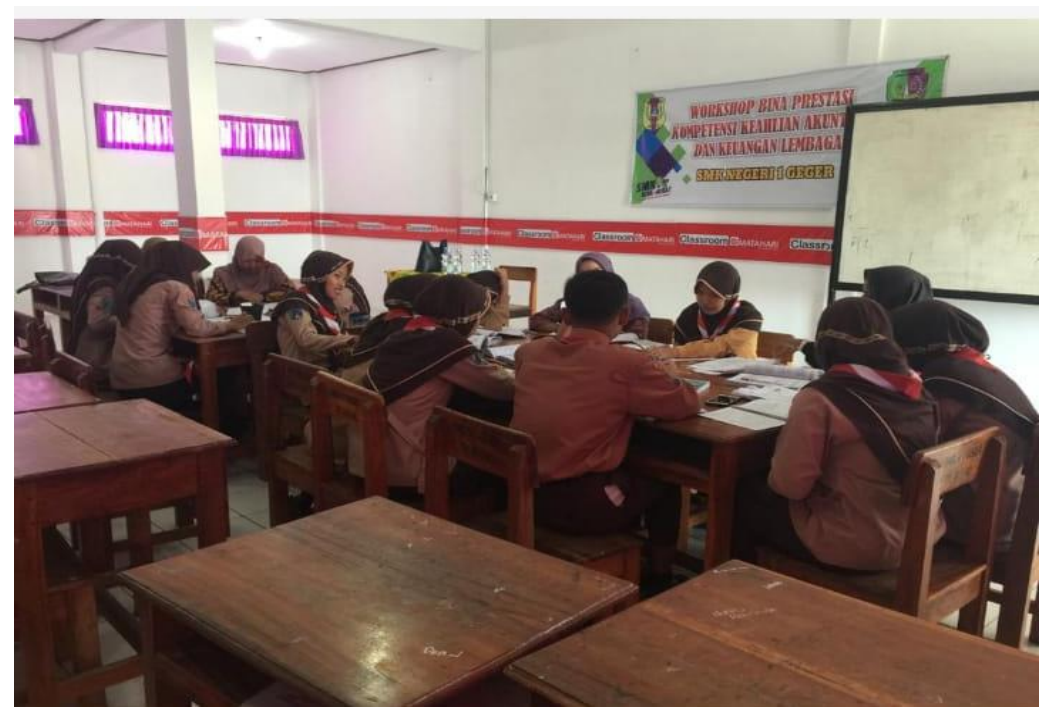

Gambar 3. Siswa Mengerjakan Soal Evaluasi

Pelaksanaan dihari ketiga terlihat siswa mengerjakan soal dengan tenang. Siswa terlihat lebih bersemangat dan hasilnya pun langsung dibahas setelah soal selesai dikerjakan. Dari hasil pengamatan siswa pun terlihat dapat lebih tenang, tidak tergesagesa dalam mengerjakan soal serta jawaban sudah terlihat siswa dapat memaparkan soal-soal akuntansi dengan pengalaman belajar sehari-hari. Siswapun dapat memberikan contoh realistis dalam kehidupan sehari-hari. Bertukar pengalaman dengan teman sebaya dan juga konsep pemecahan masalah yang disesuikan dengan karekteristik siswa diharapkan dapat membatu siswa dalam proses belajar dan kedepannya siswa dapat menemukan konsep yang lebih mudah sesuai dengan pengalamna belajar dari pengembangan sebuah teori yang ada di materi akuntansi serta dapat mengembangkan teori tersebut dengan pemahaman contoh nyata dalam kehidupan sehari-hari. 


\section{SIMPULAN DAN SARAN}

Adanya kegiatan pengabdian masyarakat ini, siswa dapat menemukan cara pemecahan masalah yang terdapat pada soal-soal mata pelajaran akuntansi. Hal ini terbukti siswa dapat memberikan pendapat dan juga pengalaman pada waktu menyelesaikan soal-soal yang diberikan dari tim pengabdian masyarakat. Dengan demikian, adanya workshop bina prestasi ini dapat menumbuhkan motivasi siswa terus untuk mencoba dan menjawab dengan strategi yang lebih mudah serta menyenangkan sehingga siswa merasa antusias ingin selalu mencoba.

\section{UCAPAN TERIMAKASIH}

Ucapan terimakasih kami berikan kepada semua pihak yang ikut membantu dan juga memberikan fasilitas dalam kegiatan pengabdian masyarakat. Terima kasih kepada pihak sekolah diantaranya kepala sekolah, guru, serta siswa - siswi keahlian akuntansi dan lembaga keuangan di SMKN 1 Geger yang sudah membeikan fasilitas sehingga pengabdian ini bisa berjalan baik dan lancar. Mahasiswa Himpunan Mahasiswa Akuntansi diantaranya Wuri.

\section{DAFTAR PUSTAKA}

Khoirul, F. (2019). Pelaksanaan Program Bina Prestasi dalam Meningkatkan soft skills siswa MTsN 6 Ponorogo (Doctoral dissertation, IAIN PONOROGO).

Nurmala, D. A., Tripalupi, L. E., \& Suharsono, N. (2014). Pengaruh motivasi belajar dan aktivitas belajar terhadap hasil belajar akuntansi. Jurnal Pendidikan Ekonomi Undiksha, 4(1)

Susilowati, E., Santosa, S., \& Hamidi, N. (2013). Pengunaan Metode Pembelajaran Drill Sebagai Upaya Meningkatkan Prestasi Belajar Akuntansi. Jupe-Jurnal Pendidikan Ekonomi, 1(3).

Syaodih, E., \& Lisnawati, C. (2018). Pendampingan Guru dalam Menemukan dan Mengatasi Kesulitan Belajar Siswa di Mts Miftahulfallah Bandung. EDUCARE, 811. 